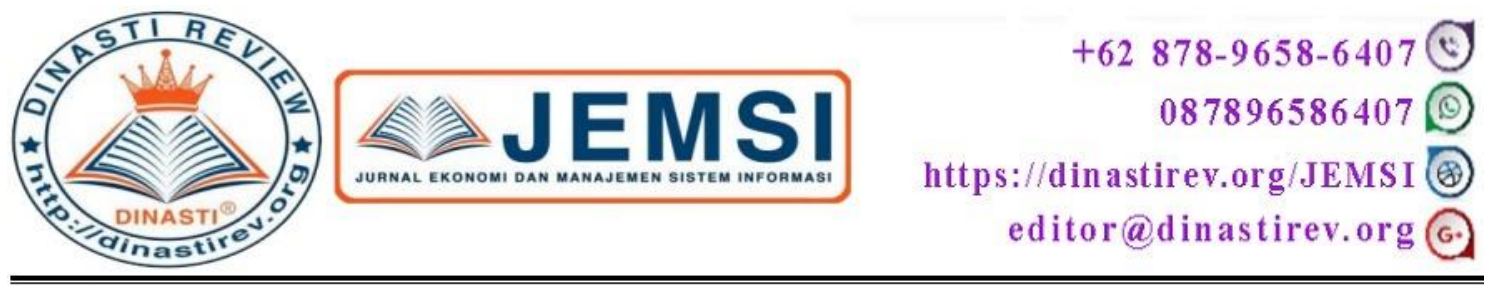

\title{
STRATEGI KOMUNIKASI PEMASARAN 10 DESTINASI PARIWISATA PRIORITAS "BALI BARU” DI KEMENTERIAN PARIWISATA REPUBLIK INDONESIA
}

\author{
Kornelia Johana $^{1)}$, Dani Setiadarma ${ }^{2)}$, Kurnia Dewi P. Wijaya ${ }^{3)}$ \\ ${ }^{1,2)}$ Fakultas Ilmu Komnikasi Universitas Dian Nusantara \\ ${ }^{3)}$ Universitas Mercu Buana
}

\begin{tabular}{|c|c|}
\hline $\begin{array}{l}\text { ARTICLE INFORMATION } \\
\text { Received: } 19 \text { April } 2020 \\
\text { Revised: 15 Juni } 2020 \\
\text { Issued: 23 Juli } 2020 \\
\text { Corresponding author: } \\
\text { Kornelia Johana } \\
\text { E-mail: } \\
\text { kornelia.johana@ undira.ac.id } \\
\text { dani.setiadarma@undira.ac.id }\end{array}$ & $\begin{array}{l}\text { Abstrak: Penelitian ini dilakukan dengan tujuan untuk } \\
\text { mengetahui strategi komunikasi pemasaran Kementerian } \\
\text { Pariwisata Republik Indonesia terkait dalam } \\
\text { mempromosikan } 10 \text { Destinasi Pariwisata Prioritas, } \\
\text { berdasarkan teori strategi humas Elvinaro Ardianto dan } \\
\text { strategi komunikasi pemasaran pariwisata Burhan } \\
\text { Bungin. Penelitian ini menggunakan penelitian deskriptif } \\
\text { kualitatif dengan metode penelitian studi kasus, } \\
\text { dilengkapi dengan wawancara mendalam kepada } \\
\text { narasumber menggunakan teknik triangulasi sumber. } \\
\text { Hasil penelitian ini membahas menganai strategi } \\
\text { komunikasi pemasaran Kementerian Pariwisata Republik } \\
\text { Indonesia dalam mempromosikan } 10 \text { Destinasi Pariwisata } \\
\text { Prioritas kepada wisatawan mancanegara dari strategi } \\
\text { humas yaitu Publikasi, Event, dan News. Selain itu juga } \\
\text { ada strategi pull dimana strategi ini menggunakan } \\
\text { kampanye Explore Futher Wonderful Indonesia melalui } \\
\text { media elektronik, cetak, dan media sosial, untuk strategi } \\
\text { push dimana strategi ini Kementerian Pariwisata } \\
\text { menerbitkan brosur, booklet, leaflet, dan calendar of } \\
\text { event. Dari hasil penelitian, bahwa pelaksanaan Asisten } \\
\text { Deputi Strategi dan Komunikasi Pemasaran } 1 \text { dalam } \\
\text { mempromosikan } 10 \text { Destinasi Pariwisata Prioritas sudah } \\
\text { cukup baik, namun harus di tingkatkan. } \\
\text { Kata Kunci: Strategi, Komunikasi Pemasaran, } \\
\text { Kementerian Pariwisata, 10 Destinasi Pariwisata } \\
\text { Prioritas. }\end{array}$ \\
\hline
\end{tabular}

\section{PENDAHULUAN}

Sektor Pariwisata merupakan salah satu sektor yang menjadi sumber devisa negera. Perkembangan pariwisata di Indonesia terus mengalami peningkatan hal ini terlihat dari banyaknya jumlah wisatawan yang berkunjung ke daerah tujuan wisata di 
Indonesia yang terkenal kaya akan keindahan alam, keramahan penduduk dan keanekaragaman budaya.

Secara Nasional Pariwisata diharapkan menjadi sektor penyumbang devisa terbesar, sedangkan secara internasional WTO (World Trade Organization), Badan Pariwisata Dunia, menegaskan bahwa pariwisata akan menjadi industri besar bersamasama dengan telekomunikasi dan teknologi informasi. Selama ini pemasukan devisa negara yang paling banyak dari sektor pariwisata berasal dari pulau Bali yang terkenal memiliki kekayaan kebudayaan dan tempat-tempat yang eksotis. Jumlahnya juga jauh diatas devisa yang dihasilkan oleh daerah wisata lainnya, bahkan Bali adalah destinasi wisata yang sudah punya pamor di peta pariwisata dunia.

10 "Bali Baru" Indonesia sendiri merupakan makna kiasan dan lebih untuk memberi tekanan agar "Performance" masing-masing daerah itu bisa menyamai Bali yang setahun bisa mendatangkan empat juta wisatawan mancanegara yang disepakati oleh Pemerintah melalui Kementerian Pariwisata sejak tahun 2016. Kunjungan Wisatawan Asing ke Bali Tahun 2016 (Data berdasarkan dari Badan Pusat Statistik Provinsi Bali) sebanyak 4.927.937. (http://bali.bps.go.id/statictable/2018)

Penetapan 10 destinasi pariwisata prioritas "Bali Baru" Indonesia merupakan amanat Presiden melalui surat Sekretariat/kabinet Nomor B 652/Seskab/Maritim/2015 tanggal 6 November 2015 perihal Arahan Presiden Republik Indonesia mengenai Pariwisata dan Arahan Presiden pada Sidang Kabinet Awal Tahun pada tanggal 4 Januari 2016.

Pesona 10 destinasi pariwisata prioritas "Bali Baru" ini mampu menarik wisatawan dengan menawarkan objek-objek wisata yang menakjubkan seperti pesona wisata alam, wisata sejarah yang bisa membuat 10 destinasi pariwisata prioritas "Bali Baru" wisata untuk wisatawan lokal maupun wisatawan mancanegara. Sesuai dengan Undang-undang No. 10 Tahun 2009 tentang Kepariwisataan, pembangunan kepariwisataan diwujudkan melalui pelaksanaan rencana pembangunan kepariwisataan dengan memperhatikan keanekaragaman, keunikan dan keunikan budaya dan alam, serta kebutuhan manusia untuk berwisata. Pembangunan kepariwisataan ini meliputi industri pariwisata, destinasi pariwisata, pemasaran pariwisataan dan kelembagaan kepariwisataan.

Melalui majalah KABARE edisi Agustus 2016, Pembangunan 10 "Bali Baru" Indonesia hingga tahun 2019, merupakan mimpi besar atau cita-cita yang besar pemerintah untuk menjaring 9,5 juta kunjungan wisatawan mancanegara dari target nasional 20 juta kunjungan wisatawan mancanegara. Sedangkan devisa yang mau diraup sebesar US\$ 9,500 miliar atau sekitar Rp 126,35 triliun (kurs Rp 13.300/US\$) dari target nasional Rp. 275 triliun.

Data grafis dibawah menunjukkan bahwa adanya perkembangan tingkat kunjungan wisatawan mancanegara ke 10 destinasi pariwisata prioritas "Bali Baru" Indonesia. Berdasarkan data Badan Pusat Statistik, total kunjungan wisatawan mancanegara ke Indonesia pada tahun 2017 mencapai 15,8 juta orang. Jumlah tersebut bertumbuh sekitar 12,58 persen dari tahun 2017 yang mencapai 14,04 juta orang. Jumlah kunjungan wisatawan mancanegara dari 5 pintu masuk utama tersebut meliputi 75,61 persen dari total kedatangan wisatawan mancanegara ke Indonesia selama 2017. Secara keseluruhan, dalam 2 tahun terakhir (2017-2018) kunjungan wisatawan mancanegara ke Indonesia 68,70 persen berasal dari Benua Asia. 
BPS (Badan Pusat Statistik) dalam laporan Statistik Kunjungan Wisatawan Mancanegara 2017 (terbit Agustus, 2018) menunjukkan 5 Pintu Masuk Utama wisman ke Indonesia, yaitu melalui: (1) Bandara Ngurah Rai, Bali sebesar 5,68 juta kunjungan atau 40,47 persen; (2) Bandara Soekarno-Hatta mencapai 2,74 juta kunjungan atau 19,58 persen; (3) Batam 11,14 persen; (4) Pelabuhan Tanjung Uban 2,65 persen; dan (5) Bandara Juanda 1,76 persen.

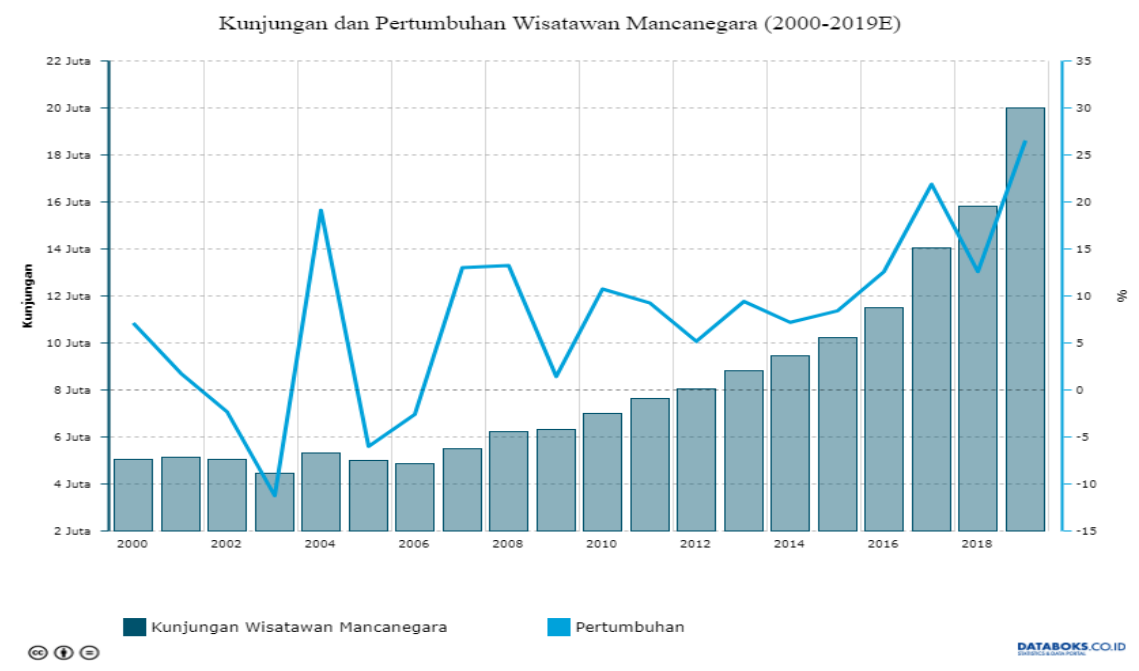

Grafik 1. Kunjungan dan Pertumbuhan Wisatawan Mancanegara (2000-2019) Sumber: Katadata.co.id

Melihat pada setiap tahunnya terjadi peningkatan kunjungan wisatawan dan banyaknya objek wisata pada 10 destinasi pariwisata prioritas "Bali Baru" dibutuhkan strategi promosi yang tepat untuk dapat mengembangkan kepariwisataan 10 destinasi pariwisata prioritas "Bali Baru" Indonesia ini terutama dalam strategi promosi. Strategi promosi pariwisata yang ada di Kementerian Pariwisata ini dinilai masih kurang. Karena kurangnya pembaharuan mengenai informasi pariwisatanya sedangkan kunjungan wisatawan lokal maupun mancanegara mengalami kenaikan setiap tahunnya.

Dalam kajian manajemen komunikasi pariwisata sendiri dalam buku Komunikasi Pariwisata, mengulas mengenai bagaimana manajemen diterapkan di bidang komunikasi pariwisata, salah satunya di tim percepatan destinasi pariwisata prioritas dengan bagaimana memenej pemasaran pariwisata, memenej destinasi, memenej asesibilitas dan memenej SDM serta kelembagaan pariwisata. Bagaimana peran pimpinan dan leadership, bagaimana memenej orang-orang, memenej anggaran dan memenej alat-alat dan mesin komunikasi pariwisata. Terpenting pula di sini bagaimana memenej berbagai macam saluran media komunikasi yang digunakan di dalam komunikasi pariwisata. Dalam arti di Asisten Deputi Strategi dan Komunikasi Pemasaran 1 menerapkan berbagai komunikasi pariwisata. 
Berdasarkan uraian diatas peneliti ingin menungkapkan lebih jauh lagi bagaimana strategi komunikasi pemasaran Asisten Deputi Strategi dan Komunikasi Pemasaran 1 Kementerian Pariwisata dalam mempromosikan destinasi wisata prioritas 10 "Bali Baru" Indonesia. Asisten Deputi Strategi dan Komunikasi Pemasaran 1 tentu memiliki strategi yang baik dalam pengembangan dan mempromosikan 10 destinasi pariwisata prioritas "Bali Baru" sehingga dapat meningkatkan kunjungan wisata. Peningkatan kunjungan wisatawan di 10 destinasi pariwisata prioritas "Bali Baru" merupakan tugas besar Asisten Deputi Strategi dan Komunikasi Pemasaran 1 untuk lebih meningkatkan strategi promosi pariwisata, baik wisata alam, bahari, maupun sejarah. Oleh karena itu, peneliti sangat tertarik untuk melakukan penelitian dengan judul "Strategi Komunikasi Pemasaran 10 Destinasi Pariwisata Prioritas "Bali Baru" di Kementerian Pariwisata Republik Indonesia”.

Berdasarkan pernyataan diatas, maka fokus penelitian ini adalah meneliti strategi komunikasi yang dilakukan oleh Kementerin Pariwisata Republik Indonesia, fokus penelitian ini mengacu pada teori Marketing Public Relations dan Komunikasi Pemasaran Pariwisata yang mengacu pada: (1) Strategi Pull dan Push; (2) Komunikasi Pemasaran Terpadu

Berdasarkan latar belakang masalah diatas, maka tujuan dari penelitian ini adalah untuk mengetahui strategi komunikasi pemasaran 10 destinasi pariwisata prioritas "Bali Baru" di Kementerian Pariwisata Republik Indonesia.

\section{KAJIAN PUSTAKA}

Komunikasi

Komunikasi adalah pertukaran pesan verbal maupun nonverbal antara si pengirim pesan dengan si penerima pesan untuk mengubah tingkah laku. Secara singkat komunikasi dapat terjadi apabila terdapat kesamaan antara penyampaian pesan dan orang yang menerima pesan. Dalam proses komunikasi yang harus sama adalah persamaan makna pesan itu. Komunikasi merupakan kebutuhan dasar dari setiap manusia, tanpa komunikasi manusia tidak akan bisa hidup dan berinteraksi. Komunikasi merupakan cara atau upaya seseorang dalam mendapatkan informasi maupun saling berbagi informasi. Komunikasi dapat terjadi apabila minimal dua orang yang saling berinteraksi memberikan informasi atau pesan. Komunikasi menurut pendapat Bernard Berelson dan Garry A. Stainer yang berasal dari buku "Ilmu Komunikasi Suatu Pengantar", yang mengatakan bahwa Komunikasi merupakan penyampaian informasi, gagasan, emosi, ketrampilan, dan sebagainya dengan menggunakan lambang-lambang ber kata-kata, gambar, bilangan, grafik dan lain- lain. Kegiatan atau proses penyampaiannya biasanya dinamakan komunikasi (Mulyana 2002).

Berdasarkan pengertian komunikasi di atas unsur-unsur dari proses komunikasi terdiri dari 5 (lima) unsur yang saling bergantungan satu sama lain, yaitu

1. Sumber (source), adalah pihak yang berinsiatif atau mempunyai kebutuhan untuk berkomunikasi. Untuk menyampaikan apa yang ada dalam hatinya (perasaan) atau pikiran tersebut ke dalam seperangkat simbol verbal dan/atau non-verbal yang idealnya dipahami oleh penerima pesan. Proses inilah yang disebut penyandian (encoding). 
2. Pesan, yaitu apa yang dikomunikasikan oleh sumber kepada penerima. Pesan merupakan seperangkat symbol verbal dan/atau non-verbal yang mewakili perasaan, nilai, gagasan atau maksud sumber tadi. Pesan mempunyai tiga komponen : makna, symbol yang digunakan untuk menyampaikan makna, dan bentuk atau organisasi pesan. Symbol terpenting adalah kata-kata (bahasa), yang dapat merepresentasikan objek (benda), gagasan dan perasaan, baik ucapan ataupun tulisan.

3. Saluran atau Media, yaitu alat atau wahana yang digunakan sumber untuk menyampaikan pesannya kepada penerima. Saluran boleh jadi merujuk pada bentuk pesan yang disampaikan kepada penerima, apakah saluran verbal atau saluran nonverbal. Pada dasarnya saluran komunikasi manusia adalah dua saluran, yakni cahaya dan suara meskipun kita bisa juga menggunakan kelima indera kita untuk menerima pesan dari orang lain.

4. Penerima (Receiver), sering juga disebut sasaran/tujuan (destination), komunikasi (communicate), penyandi-balik (decoder) atau khalayak (audience), pendengar (listener), penafsir (interpreter), yakni orang yang menerima pesan dari sumber. Berdasarkan pengalaman masa lalu, rujukan nilai, pengetahuan, persepsi, pola pikir dan perasaan, penerima pesan ini menerjemahkan atau menafsirkan seperangkat symbol verbal dan/atau non verbal yang ia terima menjadi gagasan yang dapat ia pahami. Proses ini disebut penyandian balik (decoding).

5. Efek, yaitu apa yang terjadi pada penerima setelah menerima pesan tersebut, penambahan pengetahuan (dari tidak tahu menjadi tahu), terhibur, perubahan sikap (dari setuju menjadi tidak setuju), perubahan keyakinan dan sebagainya.

Komunikasi adalah proses penyampaian pikiran atau perasaan oleh seseorang kepada orang lain dengan menggunakan lambang-lambang yang bermakna bagi kedua pihak dalam situasi tertentu, komunikasi menggunakan media tertentu untuk merubah sikap atau tingkah laku seseorang atau sejumlah orang sehingga ada efek tertentu yang diharapkan.

Komunikasi bagian dari suatu proses penyampaian makna pesan, baik berupa informasi, pendapat, dan lambang lambang yang saling dimengerti antara komunikator dan komunikan. Sehingga pesan yang diharapakan komunikator dapat mengubah tingkah laku seseorang yang menerima pesan tersebut melalui media tertentu. Komunikasi minimal dapat dilakukan minimal dua orang, baik itu komunikator dan komunikan.

\section{Marketing Public Relations}

Menurut Harris (1993) Marketing Public Relation merupakan proses perencanaan, pelaksanaan dan pengevaluasian program-program yang merangsang pembelian dan kepuasan konsumen melalui komunikasi mengenai informasi yang dapat dipercaya dan melalui kesan - kesan yang menghubungkan perusahaan dan produknya sesuai dengan kebutuhan, keinginan, perhatian dan kepentingan para konsumen. Marketing Public Relation dianggap efektif pada banyak area antara lain:

1) Marketing Public Relation dapat efektif dalam membangun brand awareness dan brand knowledge.

2) Marketing Public Relation potensial untuk membangun efektivitas pada area "increasing category usage" (menambah kategori penggunaan) dan "increasing brand sale (meningkatkan penjualan merk)". 
Untuk meningkatkan hasil yang ingin dicapai perlu adanya perpaduan antara periklanan dengan Marketing Public Relation.

Marketing Public Relation semakin penting sebab utamanya dengan semakin canggihnya teknologi media elektronik: (a) Public Relation lebih cost effective ditengah biaya media yang tinggi; (b) Dapat melengkapai iklan secara komplementer; (c) Dapat diapaki sebagai kegiatan yang dapat terpercaya serta dapat menembus situasi yang relatif sulit/terbatas

\section{Komunikasi Pemasaran}

Komunikasi pemasaran menurut Kotler dan Keller adalah sarana di mana perusahaan berusaha menginformasikan, membujuk, dan meningkatkan konsumen secara langsung maupun tidak langsung tentang produk dan merek yang dijual. Komunikasi pemasaran mempresentasikan "suara" perusahaan dan mereknya serta merupakan sarana di mana perusahaan dapat membuat dialog dan membangun hubungan dengan konsumen.

Definisi lain yang mempunyai relevansi dengan pengelolaan suatu perusahaan sebagai berikut: Komunikasi pemasaran adalah proses penyajian seperangkat rangsangan yang diintegrasikan pada sasaran pasar dengan maksud untuk menimbulkan seperangkat respon yang diinginkan, mengadakan saluran-saluran untuk menerima, menafsirkan, bertindak atas dasar pesan untuk tujuan mengubah pesan perusahaan sekarang dan mengidentifikasikan kesempatan-kesempatan komunikasi baru.

Komunikasi pemasaran merupakan pertukaran informasi dua arah antara pihak atau lembaga-lembaga yang terlibat dalam pemasaran. Pertukaran dua arah ini kadangkadang disebut sebagai lembaga yang terlibat dalam perusahaan. Pertukaran dua arah ini kadang-kadang disebut sebagai dialog pemasaran. Atau secara luas pembeli dan penjual, dan merupakan kegiatan yang membantu dalam pengambilan keputusan di bidang pemasaran serta mengarahkan pertukaran agar lebih memuaskan dengan cara menyadarkan semua pihak untuk berbuat lebih baik. Semua orang yang mendengarkan terlihat dalam proses komunikasi pemasaran melakukan cara yang sama, yaitu mendengarkan, bereaksi, dan berbicara sampai tercipta hubungan pertukaran yang memuaskan.

\section{Strategi Komunikasi Pemasaran}

Strategi Komunikasi berasal dari bahasa Yunani klasik yaitu "stratos" yang artinya tentara dan kata "agein" yang berarti memimpin. Dengan demikian strategi dimaksudkan adalah memimpin tentara. Dalam menangani masalah komunikasi, para perencana dihadapkan pada sejumlah persoalan, terutama dalam kaitannya dengan strategi yang ingin dicapai. Seorang pakar perencanaan komunikasi Middleton (1980) membuat definisi dengan menyatakan strategi komunikasi adalah kombinasi yang terbaik dari semua elemen komunikasi mulai dari komunikator, pesan saluran (media), penerima sampai pada pengaruh (efek) yang dirancang untuk mencapai tujuan komunikasi yang optimal.

Komunikasi pemasaran adalah sarana di mana perusahaan berusaha menginformasikan, membujuk, dan mengingatkan konsumen secara langsung maupun tidak langsung tentang produk dan merek yang dijual. Komunikasi pemasaran 
mempresentasikan "suara" perusahaan dan mereknya serta merupakan sarana di mana perusahaan dapat membuat dialog dan membangun hubungan dengan konsumen.

Jadi strategi komunikasi pemasaran adalah teknik komunikasi yang direncanakan dengan tujuan untuk menarik minat konsumen melalui kombinasi komunikator dan media. Menurut Kennedy dan Soemanagara, tujuan komunikasi pemasaran adalah untuk mencapai 3 tahap perubahan, yaitu:

1. Perubahan pengetahuan. Dalam tahap ini perusahaan/lembaga memberikan pengetahuan kepada konsumen tentang keberadaan produk. Untuk apa produk itu diciptakan dan ditujukkan kepada siapa.

2. Perubahan sikap. Perubahan sikap tentunya mengarah kepada keinginan untuk mencoba produk. Pada tahap ini ditentukan oleh 3 komponen yaitu: (a) Efek kognitif yaitu membentuk kesadaran informasi tertentu yang mengakibatkan perubahan pada aspek pengetahuan, kepercayaan atau keyakinan; (b) Efek afeksi yaitu memberikan pengaruh untuk melakukan sesuatu. Yang diharapkan adalah realisasi pembelian; (c) Efek kognatif yaitu membentuk pola khalayak menjadi perilaku selanjutnya. Yang diharapkan adalah pembelian uang.

3. Perubahan Perilaku

Perubahan perilaku ditujukan agar konsumen tidak beralih kepada produk lain, dan terbiasa untuk menggunakannaya. Secara umum ada tiga tingkatan dasar untuk hierarki efek dalam praktik komunikasi pemasaran. Hal ini dapat dianggap sebagai tahapan dan posisi di mana pelanggan atau khalayak merespon dan memahami suatu produk dari hasil interaksi mereka lewat komunikai pemasaran. Tahapan tersebut terbagi dalam beberapa tingkatan berikut: (a) Tahap knowings (mengetahui/ kenal); (b) Tahapan feelings (merasakan/ hasrat); (c) Tahap actions (tindakan terpengaruh)

Peran komunikasi sangat penting di dalam bidang pariwisata, baik pada aspek komponen maupun elemen-elemen pariwisata. Peran penting komunikasi bukan saja pada komponen pemasaran pariwisata namun pada semua komponen dan elemen pariwisata memerlukan peran komunikasi, baik komunikasi personal, komunikasi massa, komunikasi persuasif serta komunikasi lainnya. Dunia pariwisata sebagai kompleks produk, memerlukan komunikasi untuk mengkomunikasikan destinasi, dan sumber daya kepada wisatawan dan seluruh stakeholder pariwisata termasuk membentuk kelembagaan pariwisata.

Komunikasi membantu pemasaran pariwisata diberbagai elemen pemasaran, komunikasi berperan baik di media komunikasi maupun konten komunikasi. Di media komunikasi, tersedia berbagai macam media komunikasi sebagai saluran pemasaran, destinasi, aksesibilitas maupun saluran media SDM dan kelembagaan pariwisata. Komunikasi juga berperan menyiapkan konten pesan yang harus disampaikan kepada masyarakat atau wisatawan, tentang apa yang seharusnya mereka tahu tentang mediamedia pemasaran, tentang destinasi, aksesibilitas dan SDM serta kelembagaan pariwisata.

Komunikasi pariwisata juga dijadikan sebagai disiplin ilmu. Sebagai disiplim ilmu, komunikasi terlah berperan begitu pesat, terutama di Indonesia. Setelah reformasi, kajian-kajian komunikasi tumbuh subur dan berkembang secara multilinear membangun disiplin-disiplin ilmu baru yang memperkaya khazanah disiplin ilmu komunikasi. 


\section{Humas Pemerintah}

Lembaga-lembaga pemerintah baik pusat maupun daerah bertanggung jawab untuk memberikan informasi kepada penduduknya mengenai segala macam kebijakan dan program yang telah, tengah, dan akan dilancarkan oleh pemerintah. Pemerintah Negara-negara berkembang menghadapi tantangan public relations yang sangat besar. Sehubung dengan tantangan tersebut, wajar bila lembaga-lembaga pemerintah lebih membutuhkan praktisi humas yang handal dari pada sektor-sektor serta komersial swasta.

Humas pemerintah adalah aktifitas lembaga yang melakukan fungsi manajemen dalam bidang komunikasi dan informasi. Humas pemerintah berperan membuka akses saluran dan komunikasi dua arah, antara instansi pemerintah dan publik atau sebaliknya, baik secara langsung maupun tidak langsung.

Saat ini peran humas di instansi pemerintah tidak bisa dipandang sebelah mata. Seiring dengan tuntutan reformasi termasuk reformasi dibidang birokrasi, pemerintah wajib menyelenggarakan aktivitasnya dengan memenuhi kriteria asas-asas pemerintah yang baik dengan "transparancy" menjadi salah satu ukuran dari suatu penyelenggaraan pemerintah. Masyarakat berhak mengetahui informasi apapun dari pembuat dan pelaku kebijakan, begitu juga sebaliknya pemerintah wajib mencari tahu apa yang sedang terjadi, bagaimana kedudukan instansinya di mata masyarakat, seperti apa pemberitaan yang ada ataupun opini publik yang tercipta.

Selain keluar, Humas pemerintah juga harus memungkinkan untuk memberi masukan mengenai kemungkinan reaksi masyarakat akan kebijakan instansi, baik yang sedang dilaksanakan, akan dilaksanakan ataupun yang sedang diusulkan. Di dunia pemerintah, humas bertugas menjalankan kegiatan kebijakan publik dan pelayanan publik. Salah satu kegiatan humas pemerintah dalam bidang kebijakan publik adalah memberi berbagai informasi tentang kebijakan pemerintah yang mengikat rakyat atau masyarakat.

Humas pemerintah memiliki posisi yang sangat strategis dalam melakukan kegiatan komunikasi, koordinat, dan menyebarluaskan berbagai data dan informasi publik yang dibutuhkan oleh para stakeholders. Humas juga berperan penting dalam melakukan sosialisasi berbagai peraturan perundang-undangan, visi dan misi, tujuan, sasaran, kebijakan, strategi, program dan rencana tindakan yang terkait dengan informasi pembangunan yang telah atau sedang dan akan dilakukan oleh pemerintah saat ini. Penyampaian data dan informasi tersebut harus dilakukan dengan citra dan itikad yang baik, saling menghargai, dan toleransi.

\section{METODE}

Paradigma yang digunakan dalam penelitian ini menggunakan paradigma postpositivistik. Paradigma postpositivistik lahir sebagai paradigma yang ingin memodifikasi kelemahan-kelemahan yang terdapat pada paradigma positivistik. Paradigma postpositivistik berpendapat bahwa peneliti tidak bisa mendapatkan fakta dari suatu kenyataan apabila si peneliti membuat jarak dengan kenyataan yang ada. Hubungan peneliti dengan realitas harus bersifat interaktif. Oleh karena itu perlu menggunakan prinsip triangulasi, yaitu penggunaan bermacam-macam metode, sumber data, dan data. 
Menurut Ardianto (2016) dikatakan metode deskriptif kualitatif termasuk paradigma penelitian postpositivistik. Asumsi dasar yang menjadi inti paradigma penelitian post-positivistik adalah:

a) Pengetahuan dibentuk oleh data, bukti dan pertimbangan logis. Dalam praktiknya, peneliti mengumpulkan informasi dengan menggunakan instrument pengukuran tertentu yang diisi oleh partisipan atau dengan melakukan observasi mendalam di lokasi penelitian.

b) Penelitian harus mampu mengembangkan pernyataan yang relevan dan benar, pernyataan yang dapat menjelaskan situasi yang sebenarnya atau mendeskripsikan relasi kausalitas dari suatu persoalan. Dalam penelitian kualitatif, membuat relasi antarvariabel dan mengemukakan dalam pertanyaan dan hipotesis.

c) Aspek terpenting dalam penelitian adalah sikap objektif. Para penelitian harus menguji kembali metode dan kesimpulan yang sekiranya mengandung bias.

Metode penelitian yang digunakan dalam penelitian ini adalah studi kasus. Menurut Raco, studi kasus adalah bagian dari metode kualitatif yang hendak mendalami suatu kasus tertentu secara lebih mendalam dan melibatkan pengumpulan aneka sumber informasi. Daymon mengungkapkan studi kasus merupakan pengujian intensif menggunakan berbagai sumber bukti terhadap suatu entitas tunggal yang dibatasi oleh ruang dan waktu.

Studi kasus memiliki beberapa keuntungan. Menurut Lincoln dan Guba mengemukakan bahwa salah satu keistimewaan studi kasus adalah studi kasus menyajikan uraian menyeluruh yang mirip dengan apa yang dilami pembaca dalam kehidupan sehari-hari. Oleh krena itu, peneliti memilih studi kasus agar uraian yang disajikan dapat mudah dipahami dan dapat loebih mudah diaplikasikan di kehidupan nyata.

\section{Subyek Penelitian}

Dalam penelitian menggunakan beberapa narasumber yang berkompeten. Narasumber yang sangat membantu peneliti dalam penelitian ini yaitu: 1) Kassubidang Analisis Data dan Informasi Pasar Asisten Deputi Strategi dan Komunikasi Pemasaran 1; 2) Kepala Bidang Multimedia Asisten Deputi Strategi dan Komunikasi Pemasaran 1; 3) Staff Travel Agent (Golden Rama Travel); 4) Traveller. Peneliti memilih beberapa traveller sebagai narasumber untuk di wawancarai guna untuk mengetahui strategi komunikasi pemasaran yang dilakukan oleh Kementerian Pariwisata Republik Indonesia serta kesan dan pesan mereka terhadap 10 Destinasi Pariwisata Prioritas "Bali Baru”.

\section{Teknik Analisis Data}

Menurut Moleong dalam buku Elvinaro (2010), analisis data adalah proses mengorganisasikan dan mengurutkan data ke dalam pola, kategori, dan satuan uraian dasar sehingga tema dapat ditemukan dan hipotesis kerja dapat dirumuskan seperti yang disarankan oleh data. Berikut langkah-langkah dalam analisis data secara kualitatif:

1) Mereduksi data. Data yang diperoleh dalam lapangan ditulis dalam bentuk uraian atau laporan yang perinci. Laporan ini akan terus menerus bertambah. Data yang direduksi memberi gambaran yang lebih tajam tentang hasil pengamatan, juga mempermudah peneliti untuk mencari kembali data bila diperlukan. 
2) Mengambil kesimpulan. Dengan mencari pola, tema, hubungan, persamaan, hal-hal yang sering timbul, hipotesis, dan sebagainya peneliti berusaha mencari makna data yang telah dikumpulkan.

\section{Teknik Pemeriksaan Keabsahan Data}

Pemeriksaan keabsahan data sangat diperlukan dalam penelitian kualitatif. Menurut Moleong, teknik keabsahan data adalah dengan mengunakan teknik triangulasi. Hal ini merupakan salah satu pemeriksaan keabsahan data yang memanfaatkan sesuatu yang lain diluardata untuk keperluan pengecekan atau sebagai pembanding terhadap data itu. Melalui teknik pemeriksaan ini, peneliti menggunakan teknik triangulasi sumber. Kemudia pemeriksaan melalui sumber dengan cara membandingkan data hasil pengamatan dan wawancara dengan Narasumber.

\section{HASIL DAN PEMBAHASAN}

\section{Hasil Penelitian}

Pada wawancara yang pertama peneliti melakukan wawancara salah satu Narasumber dari divisi Asisten Deputi Strategi dan Komunikasi Pemasaran 1, yaitu Bapak Faruk sebagai Kassubidang Analisis Data dan Informasi Pasar Deputi Bidang Pengembangan Pemasaran 1.

"Strategi yang digunakan oleh Asisten Deputi Strategi dan Komunikasi Pemasaran 1 dalam mempromosikan 10 Destinasi Pariwisata Prioritas atau "BaliBaru" ada 2 strategi yaitu yang pertama ada BAS (Branding, Advertising, dan Selling) dan yang kedua POSE (Paid Media, Owned Media, Social Media, Endorser) Strategi ini yang digunakan oleh Asisten Deputi Strategi dan Komunikasi Pemasaran 1 karena dianggap sangat efektif dalam mempromosikan 10 Destinasi Pariwisata Prioritas."

Data kenaikan kunjungan Wisatawan ke 10 Destinasi Pariwisata Prioritas "Bali Baru" dapat dilihat di Grafik di bawah ini. Berdasarkan data tersebut terlihat kenaikan kunjungan Wisatawan dalam periode tahun 2018. Berarti dapat disimpulkan Strategi dari divisi Asisten Deputi Strategi dan Komunikasi Pemasaran 1 dalam mempromosikan 10 Destinasi Pariwisata Prioritas sudah berjalan efektif.

Setelah dijelakan sedikit tentang apa saja strategi yang dilakukan oleh Asisten Deputi Strategi dan Komunikasi Pemasaran 1 dalam melakukan promosi 10 Destinasi Pariwisata Prioritas dapat diketahui Kementerian Pariwisata Republik Indonesia melakukan strategi Branding, Advertising, Selling, Paid Media, Owned media, Social Media, Endorser. Branding disini yaitu salah satunya Asisten Deputi Strategi dan Komunikasi Pemasaran 1 melakukannya dengan cara mengendorse para public figure nasional maupun internasional dan beauty pageant (kontes kecantikan) seperti Puteri Indonesia, Miss Grand Indonesia, dan Puteri Pariwisata Indonesia dalam mempromosikan 10 Destinasi Pariwisata Prioritas "Bali Baru".

Narasumber lainnya dari Divisi Asisten Deputi Strategi dan Komunikasi Pemasaran 1, Bapak Hafiz yang menjabat sebagai Kepala Bidang Multimedia mengatakan bahwa ada hambatan dalam melakuakan promosi 10 Destinasi Pariwisata Prioritas "Bali Baru".

"Hambatan dalam melakukan promosi 10 Destinasi Pariwisata Prioritas yaitu anggaran yang masih minim untuk mengangkat 10 Destinasi Pariwisata Prioritas 
menjadi destinasi yang dikenal secara mendunia. Selain itu masih banyak wisatawan nusantara maupun mancanegara yang belum mengenal lokasi-lokasi 10 Destinasi Pariwisata Prioritas, infrastruktur yang minim (belum sempurna untuk kegiatan bisnis), persaingan dengan Bali dan dengan destinasi luar negeri dan terakhir harga tiket yang mahal membuat wisatawan berpikir lagi untuk mengunjungi 10 Destinasi Pariwisata Prioritas. Tetapi hal ini tidak menjadi halangan bagi kami untuk tetap melakukan promosi 10 Destinasi Pariwisata Prioritas. Strategi yang kami gunakan dalam memromosikan 10 Destinasi Pariwisata ini salah satunya selling."

Dari yang dijelaskan oleh Bapak Hafiz keterbatasan anggaran promosi tidak menjadi hambatan dalam melakukan promosi 10 Destinasi Pariwisata Prioritas. Strategi selling pun dilakukan melalui pameran, misi penjualan, festival (luar negeri) dan kerjasama dengan maskapai penerbangan, Ferry, dan Wholesaler.

Selain Selling promosi, Kementerian Pariwisata Republik Indonesia juga mempunyai program yang bekerja sama dengan Kedutaan Besar yaitu kegiatan memfasilitasi jurnalis luar negeri atau travel agent dari luar negeri ke 10 Destinasi Pariwisata Prioritas mendampingi mereka mengunjungi objek wisata.

"Kami bekerja sama dengan travel agent. Kami ajak para travel agent ke destinasi yang sedang kita angkat, jadi mereka bisa mengetahui apa yang akan mereka jual, dan selain itu kami kerjasama dengan travel agent dalam menciptakan paket-paket hot deals. Kita ajak semua elemen mulai dari airlines, hotel, maupun restoran."

\section{Branding}

Setiap brand yang terjadi akan sangat mempengaruhi kesan maupun pesan yang di terima oleh para wisatawan nusantara maupun mancanegara. Pesan dan kesan yang di terima wisatawan nantinya akan sangat berpengaruh kepada kedatangan wisatawan ke 10 Destinasi Pariwisata Prioritas "Bali Baru". Image yang baik merupakan kunci sebuah kesuksesan. Keanekaragaman, keunikan budaya dan alam dapat memberikan poin tambahan kepada 10 Destinasi Pariwisata Prioritas "Bali Baru". Sehingga memberi kemudahan kepada Kementerian Pariwisata Republik Indonesia dalam mempromosikan 10 Destinasi Pariwisata Prioritas.

Selain itu dalam upaya meningkatkan jumlah wisatawan, Kementerian Pariwisata melakukan promosi keluar negeri dengan logo Wonderful Indonesia sebagai benderanya. Logo tersebut ditampilkan melalui Billboard, bis pariwisata, dan kereta di beberapa negara, menurut Bapak Faruk dengan adanya promosi dengan cara tersebut, Indonesia sudah ada jumlah peningkatan wisatawan dari mancanegara.

"Kami menggunakan logo Wonderful Indonesia untuk membangun brand pariwisata Indonesia. Logo ini kami tampilkan di billboard, bis pariwisata, kereta di beberapa negara. Dengan cara tersebut wisatawan mancanegara tertarik untuk mengunjungi pariwisata Indonesia."

Wonderful Indonesia merupakan langkah yang sudah lama dilakukan oleh Kementerian Pariwisata Republik Indonesia dalam membangun brand destinasi. Untuk meningkatkan wisatawan 10 Destinasi Pariwisata Prioritas, pihak Kementerian Pariwisata juga bekerja sama dengan Dinas Pariwisata Provinsi lainnya dan menggunakan travel agent sebagai local operator dalam kegiatan pemasaran, baik itu secara langsung maupun tidak langsung.

\section{Advertising}


Selain itu untuk menginformasikan berbagai pesan dan programnya kepada masyarakat dan wisatawan, sebelum dan selama kegiatan 10 Destinasi Pariwisata Prioritas, Kementerian Pariwisata Republik Indonesia juga melakukan beberapa periklanan dibeberapa saluran media massa seperti surat kabar, majalah, internet, media luar ruangan, billboard, poster, dan lain-lain. Untuk menginformasikan kepada khalayak, selama dan sebelum 10 Destinasi Pariwisata Prioritas.

Selain beberapa media yang telah disebutkan diatas, Kementerian Pariwisata Republik Indonesia dalam melakukan promosi dan meningkatkan wisatawan mancanegara, melalui Asisten Deputi Strategi dan Komunikasi Pemasaran memiliki tugas mencari data dan informasi mengenai tempat wisata, alamat-alamat hotel, alamatalamat biro perjalanan dan semua informasi yang dibutuhkan oleh wisatawan yang kemudian data yang didapat dibuat booklet dan calendar of event disebarkan melalui TIC (Tourism Informations Center).

Selain itu Kementerian Pariwisata mempromosikan 10 Destinasi Pariwisata Prioritas melalui website dan media sosial juga dilakukan untuk para calon wisatawan yang berada di tempat yang jauh, namun menjadi "dekat" apabila memanfaatkan media internet.

\section{Selling}

Promosi penjualan (Selling) merupakan aktivitas promosi yang bertujuan menggugah penjualan pada suatu waktu tertentu. Dalam pelaksanaannya promosi penjualan bersifat jangka pendek, menawarkan imbalan, melahirkan reaksi cepat, berorientasi pada penjualan, membedakan diri dengan pesaing pada kesempatan tertentu, serta memberi nilai aktual terhadap produk dan jasa yang ditawarkan.

Selain itu Amelia mengatakan juga bahwa Kementerian Pariwisata melakukan strategi komunikasi pemasaran dinilai masih kurang. Dalam melakukan promosi saja masih samar. Calon wisatawan lokal sendiri masih memilih untuk pergi liburan ke Bali atau ke luar negeri akibat harga tiket dalam negeri dan transportasi yang masih susah. Strategi Komunikasi Pemasaran yang dilakukan Kementerian Pariwisata Republik Indonesia dinilai masih kurang, seperti yang dikatakan oleh Rony Anwar selaku Traveller sebagai berikut:

"Sangat kurang sekali strategi komunikasi pemasaran yang dilakukan karena tidak sampai ke lapisan bawah. Untuk yang sering travelling saja masih banyak yang belum tahu karena kurang informasi baik di tempat umum ataupun tempat wisata itu sendiri."

Hal itu juga tidak hanya dikatakan oleh Rony saja tetapi Verry sebagai Traveller juga merasakan hal yang sama bahwa strategi yang dilakukan Kementerian Pariwisata Republik Indonesia masih kurang.

"Walaupun saya pernah diajak Kementerian Pariwisata sebagai Endorser, saya menilai masih kurang sekali ya, melalui media pun yang saya liat juga samar. Kurang gencar dalam melakukan promosi. Saya saja kalau mau pergi sendiri (single trip) untuk referensi mau pergi kemana itu paling melihat dari para influencer."

Peneliti juga mewawancarai traveler asing berasal dari Amerika yaitu Mr. Jeremy tentang 10 Destinasi Pariwisata Prioritas. Beliau mengetahui 10 destinasi pariwisata prioritas ini dari media sosial, website, event, dan brosur Kementerian Pariwisata.

"I knew about $10 \mathrm{New}$ Bali from media social, website, event, and brocur the Ministry of Tourism Indonesia and I just went to several places there are Danau Toba, Belitung, 
Wakatobi, Borobudur. For the next trip, I'll going to Tanjung Lesung and Kepulauan Seribu."

Selain itu juga Mr. Jeremy mengakui sangat terpukau terhadap keindahan wisata yang ada di Indonesia. Tetapi beliau sangat menyayangkan masih ada kesulitan dalam transportasi menuju wisata-wisata tersebut dan beliau juga sedikit kecewa terhdap adanya perbedaan harga pada wisatawan asing dan wisatawan mancanegara. Beliau berharap Kementerian Pariwisata meningkatkan fasilitas untuk mempermudah para wisatawan menuju ke destinasi-destinasi yang ada di Indonesia.

Dalam menggencarkan aktivitas promosi 10 Destinasi Pariwisata Prioritas, Kementerian Pariwisata Republik Indonesia juga melaksanakan berbagai program kerja. Salah satunya yaitu melakukan perbaikan objek wisata dan fasilitas di sekitar 10 Destinasi Pariwisata Prioritas. Selain itu juga Kementerian Pariwisata melakukan evaluasi setiap tahunnya agar dapat meningkatkan kekurangan yang ada.

\section{Pembahasan}

10 Destinasi Pariwisata Prioritas "Bali Baru" masing-masing memiiliki potensi wisata yang menarik, namun masih ada beberapa yang kurang maksimal dalam pengelolaannya terutama dari segi informasi yang diberikan, sarana transportasi serta fasilitas yang memadai di setiap obyek wisata 10 Destinasi Pariwisata. Maka dari itu 10 Destinasi Pariwisata Prioritas masih kalah dengan Bali, dimana Bali mengalahkan negaranya sendiri Indonesia karena kepopulerannya. Butuh kerjasama dari berbagai pihak dalam mengelola dan memasarkan 10 Destinasi Pariwisata Prioritas sebagai destinasi favorit bagi wisatawan nusantara maupun mancanegara.

Untuk mempromosikan 10 Destinasi Pariwisata Prioritas, Kementerian Parwisata Republik Indonesia menggunakan strategi komunikasi pemasaran. Elemen-elemen komunikasi yang digunakan yaitu Branding, Advertising, Selling, Paid Media, Owned Media (Website), Social Media,dan Endorser. Promosi dilakukan oleh Kementerian Pariwisata untuk mempromosikan 10 Destinasi Pariwisata Prioritas kepada wisatawan nusantara maupun mancanegara, sehingga wisatawan dapat mengenal, tertarik dan selalu ingat lokasi-lokasi 10 Destinasi Pariwisata Prioritas, selain itu pada event-event yang di selenggarakan 10 Destinasi Pariwisata Prioritas.

Dalam mengkomunikasikan 10 Destinasi Pariwisata Prioritas ke mancanegara, Kementerian Pariwisawa Republik Indonesia menggunakan komunikasi pemasaran untuk menyampaikan informasi kepada wisatawan mancanegara.

Strategi Asisten Deputi Strategi dan Komunikasi Pemasaran 1 untuk menarik minat wisatawan nusantara maupun mancanegara dibutuhkan kegiatan promosi yang sangat penting bagi perkembangan 10 Destinasi Pariwisata Prioritas. Kementerian Pariwisata telah melakukan beberapa promosi tetapi masih di rasa kuran gencar.

Usaha peningkatan pariwisata dilakukan dengan cara brand, brand merupakan identias dan khalayaklah yang menilai dan merasakan dampaknya. Membentuk brand yang baik sangatlah penting. 10 Destinasi Pariwisata Prioritas agar dikenal dan diketahui oleh wisatawannusantara maupun mancanegara, Kementerian Pariwisata menggunakan brand melalui logo "Wonderful Indonesia". Dengan logo ini diharapkan wisatawan mancanegara dapat menaruh kepercayaannya untuk berkunjung ke Indonesia. Logo tersebut disebarkan oleh Kementerian Pariwisata dengan bantuan 
KBRI (Kedutaan Besar Republik Indonesia) dibeberapa negara dengan media Billboard, transportasi, dan majalah-majalah wisata.

Iklan adalah bentuk komunikasi massa yang bersifat membujuk dan mempengaruhi. Kementerian Pariwisata Republik Indonesia banyak menggunakan media iklan dalam mepromosikan 10 Destinasi Pariwisata Prioritas. Kementerian Pariwisata sangat selektif dalam menggunakan media iklan dalam memromosikan 10 Destinasi Pariwisata Prioritas.

Pada media cetak Kementerian Pariwisata melakukan promosi melalui surat kabar. Tidak hanya menggunakan surat kabar dalam negeri saja, Kementerian Pariwisata juga menggunakan surat kabar luar negeri. Periklanan dilakukan pada media surat kabar hampir setiap hari selama berlangsungnya jadwal kegiatan event di setiap lokasi 10 Destinasi Pariwisata Prioritas.

Media cetak, oleh Kementerian Pariwisata Republik Indonesia juga menggunakan brosur. Dengan brosur informasi yang diberikan kepada para wisatawan nusantara maupun mancanegara dapat menambah informasi para wisatawan, sehingga brosur yang diberikan mengarah pada tujuan komunikasi pemasaran yaitu menginformasikan, membujuk dan mengingatkan akan adanya event di setiap lokasi 10 Destinasi Pariwisata Prioritas.

Selain media cetak, Kementerian Pariwisata Republik Indonesia dalam mempromosikan 10 Destinasi Pariwisata Prioritas juga melakukan promosi melalui media elektronik yaitu radio dan televisi. Radio yang digunakan untuk iklan adalah sebagian besar radio pemerintah dan beberapa radio swasta untuk mempromosikan 10 Destinasi Pariwisata Prioritas. Selain itu pada televisi Kementerian Pariwisata juga menyiarkan iklannya tidak hanya televisi dalam negeri tetapi luar negeri juga.

Media luar ruang merupakan media yang dipilih oleh Kementerian Pariwisata Republik Indonesiadalam beriklan, mulai dari spanduk, billboard, dan poster sehingga 10 Destinasi Pariwisata Prioritas dapat dilihat oleh para wisatawan.

Selain menyebarkan booklet dan calendar of event, Kementerian Pariwisata Republik Indonesia juga mengadakan program bernama Fams Trip yaitu mendatangkan buyers dari luar negeri. Para buyers diajak untuk mengunjungi dan memperkenalkan 10 Destinasi Pariwisata Prioritas ke luar negeri. Tujuan dari mendatangkan buyers adalah agar para buyer berkunjung ke setiap 10 Destinasi Pariwisata Prioritas dengan serta mengajak teman, keluarga,dan sahabat, dan membeli produk-produk yang dihasilkan masyarakat. Hal ini tentu saja akan mensejahterakan masyarakat sekitar sekaligus mendatangkan devisa bagi negara.

Selain itu juga Kementerian Pariwisata juga mengundang para endorser untuk mempromosikan 10 Destinasi Pariwisata Prioritas sebagai testimonial agar wisatawan nusantara maupun wisatawan mancanegara mau berkunjung ke lokasi-lokasi 10 Destinasi Pariwisata Prioritas.

Promosi yang rutin dilakukan oleh Kementerian Pariwisata Republik Indonesia adalah pameran dan event. Pameran dan event yang merupakan salah satu cara Kementerian Pariwisata Republik Indonesia untuk melakukan promosi penjualan. Pameran dan event yang di ikuti tidak hanya di dalam negeri tapi di luar negeri juga.

Selain melakukan periklanan dan promosi Kementerian Pariwisata Republik Indonesia juga melakukan selling. Kepada para wisatawan baik wisatawan nusantara maupun mancanegara tentang lokasi-lokasi 10 Destinasi Pariwisata Prioritas. Bentuk 
pemasaran ini yang dilakukan Kementerian Pariwisata dengan mengikuti perkembangan jaman yaitu melalui media internet. Cara yang digunakan adalah selalu mengupdate informasi tentang 10 Destinasi Pariwisata Prioritas di berbagai macam media sosial seperti Facebook, Twitter, Instagram, Youtube, dan website. Tujuannya agar wisatawan nusantara maupun mancanegara lebih mudah mengetahui informasi yang diberikan oleh Kementerian Pariwisata.

Kesimpulan yang diperoleh dari hasil analisa mengenai strategi komunikasi pemasaran yang dilakukan oleh Asisten Deputi Strategi dan Komunikasi Pemasaran 1 dalam mempromosikan 10 Destinasi Pariwisata Prioritas yaitu membujuk dan mempengaruhi para calon wisatawan nusantara maupun mancanegara untuk berkunjung ke lokasi-lokasi 10 Destinasi Pariwisata Prioritas, mempromosikan tempat tujuan wisata dilakukan secara terprogram dan terarah yang di mana setiap program yang dilakukan bersifat terencana seperti melakukan promosi yang dilakukan oleh Kementerian Pariwisata Republik Indonesia dalam mempromosikan 10 Destinasi Pariwisata Prioritas.

Setiap program yang direncakan akan dilaksanakan dan dievaluasi mengenai optimasl atau tidaknya pelaksanaan strategi promosi yang dilakukan oleh Kementerian Pariwisata Republik Indonesia.

Asisten Deputi Strategi dan Komunikasi Pemasaran 1 tentunya selalu melakukan evaluasi dan pelaporan mengenai promosi 10 Destinasi Pariwisata Prioritas setiap tahunnya yang bertujuan untuk memperbaiki program dalam meningkatkan wisatawan nusantara maupun mancanegara mengunjungi lokasi-lokasi 10 Destinasi Pariwisata Prioritas.

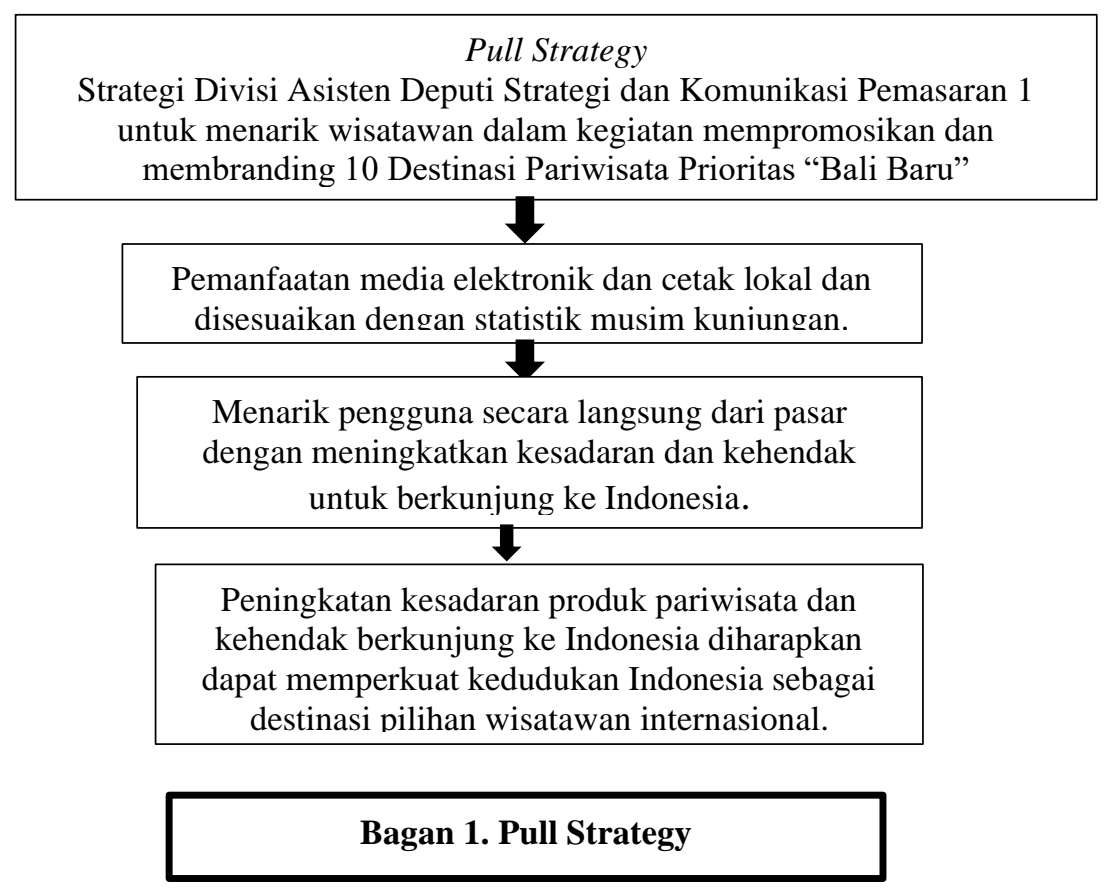




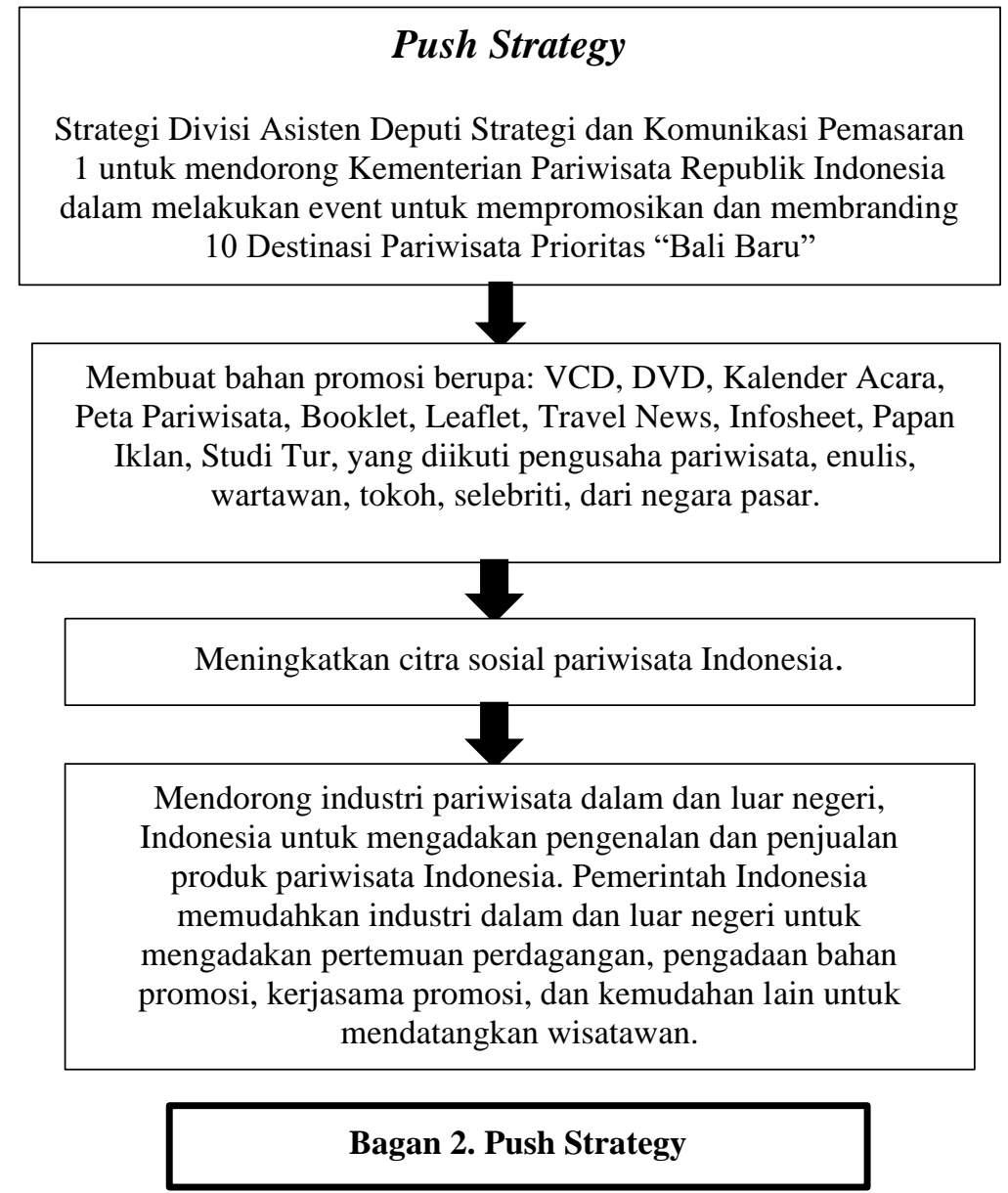

\section{PENUTUP}

\section{Simpulan}

Pada bagian akhir dari skripsi ini, peneliti akan mengemukakan kesimpulan yang di dapat dari hasil penelitian dan uraian pada bab-bab sebelumnya mengenai yang diteliti yaitu Strategi Komunikasi Pemasaran 10 Destinasi Pariwisata Prioritas "Bali Baru" di Kementerian Pariwisata Republik Indonesia. Dimana Kementerian Pariwisata Republik Indonesia saat ini sedang gencar mempromosikan 10 Destinasi Pariwisata Prioritas dalam meningkatkan wisatawan nusantara dan tercapainya 20 juta kunjungan wisatawan mancanegara. Selain mepromosikan, Kementerian Pariwisata juga sedang melakukan pengembangan pada setiap 10 Destinasi Pariwisata Prioritas seperti membangun akses ke objek wisata lebih baik dan fasilitas yang lebih memadai.

Setelah melakukan penelitian di Kementerian Pariwisata Republik Indonesia, mengenai strategi komunikasi pemasaran pariwisata Asisten Deputi Strategi dan Komunikasi Pemasaran dalam mempromosikan 10 Destinasi Pariwisata Prioritas dengan strategi Pull dan Push, yaitu dari buku Burhan Bungin yang berjudul Komunikasi Pariwisata.

Strategi pull yang dilakukan dalam program kampanye "Explore Further Wonderful Indonesia" (Luar Negeri) digunakan untuk meningkatkan kesadaran bahwa keindahan pariwisata tidak hanya ada Bali saja, dengan program ini di harapkan 
wisatawan berpotensial dapat mengunjungi lokasi-lokasi 10 Destinasi Pariwisata Prioritas. Mempromosikan 10 Destinasi Pariwisata Prioritas disebarkan melalui media elektronik seperti televisi dan radio, media cetak seperti koran dan majalah, dan media sosial seperti Instagram, Twitter, Youtube, dan Website dalam negeri maupun luar negeri agar para wisatawan lebih mudah mengetahui informasi dan tertaik untuk berkunjung ke lokasi-lokasi 10 Desinasi Pariwisata Prioritas. Kementerian Pariwisata Republik Indonesia terus berusaha lebih gencar dalam mempromosikan 10 Destinasi Pariwisata Prioritas ini.

Strategi push yang dilakukan Kementerian Pariwisata Republik Indonesia dalam mepromosikan 10 Destinasi Pariwisata Prioritas adalah menerbitkan brosur, booklet, leaflet, peta pariwisata, buku panduan, papan iklan dan calendar of event. Kementerian Pariwisata juga mengikuti berbagai cara untuk mempromosikan 10 Destinasi Pariwisata Prioritas seperti Travel Fair di luar negeri dan bekerja sama dengan beberapa beauty pageant. Strategi push ini digunakan karena anggaran pemasaran terbatas, sehingga iklan di media massa elektronik dan cetak diminimumkan.

Komunikasi pemasaran terpadu Kementerian Priwisata Republik Indoneia adalah bekerja sama dengan beberapa travel agent atau perusahaan jasa pariwisata luar negeri. Bermodalkan table list harga objek wisata, Kementerian Pariwisata menyebarkan ke beberapa travel agent untuk dibuatkan sebuah paket berikut hotel dan transportasi. Ini tentunya menguntugan sekali bagi pemerintah, travel agent itu ibarat marketingnya Kementerian Pariwisata.

\section{Saran}

Diharapkan hasil penelitian ini dapat menjadi referensi, masukan bagi pengembangan ilmu komunikasi dan referensi bagi mahasiswa yang akan melakukan penelitian sejenis. Peneliti mengharapkan untuk penelitian lanjutan, peneliti lainnya dapat menggunakan pendekatan penelitian yang berbeda agar untuk melihat perbandingan pembuatan dan pelaksanaan Strategi Komunikasi Pemasaran, Marketing Public Relations, dan Publikasi 10 Destinasi Pariwisata Prioritas sehingga hasilnya dapat saling melengkapi dan diharapkan adanya temuan baru.

Peneliti mencoba memberikan saran kepada Asisten Deputi Strategi dan Komunikasi Pemasaran 1 dalam merancang strategi komunikasi pemasaran dalam mempromosikan 10 Destinasi Pariwisata Prioritas, yaitu: (1) Meningkatkan strategi komunikasi pemasaran dalam mempromosikan 10 Destinasi Pariwisata Prioritas, promosi yang dilakukan oleh Kementerian Pariwisata Republik Indonesia masih kurang dan tidak terlalu efektif. Sehingga strategi Asisten Deputi Strategi dan Komunikasi Pemasaran 1 yaitu BAS (Branding, Advertising, Selling) dan POSE (Paid Media, Owned Media, Social Media, Endorser) tetap di jalankan, lebih gencar lagi dalam mempromosikan, dan di evaluasi setiap tahunnya agar menjadi semakin baik kedepannya. (2) Perlunya meningkatkan kerjasama Kementerian Pariwisata Republik Indonesia dengan pihak-pihak swasta seperti travel agent dan pelaku pendukung pariwisata sehingga terjalin kerjasama yang baik untuk mempromosikan 10 Destinasi Pariwisata Prioritas. 


\section{DAFTAR RUJUKAN}

Arni, Muhamad, (2011). Komunikasi Organisasi, (Jakarta: PT Bumi Aksara)

AR Bulaeng,(2002). Komunikasi Pemasaran, (Jakarta: Universitas Terbuka

Arifin, A. (1984). Strategi Komunikasi. Bandung: CV Amirco.

Bulaeng, A. (2002). Komunikasi Pemasaran. Jakarta: Universitas Terbuka.

Bungin, B. (2015). Komunikasi Pariwisata: Pemasaran dan Brand Destinasi. Jakarta: Pranadamedia Group.

Elvinaro, A. (2010). Metodologi Penelitian untuk Public Relations-Kuantitatif dan Kualitatif. Jakarta: Simbiosa Rekatama.

Elvinaro Ardianto, (2016). Metodologi Penelitian untuk Public Relations Kualitatif dan Kuantitatif. Bandung: Simbiosa Rekatama Media.

H., Y. O. (1982). Dalam Pengantar Ilmu Pariwisata. Bandung: Angkasa Bandung.

John E. Kennedy dan R. Dermawan Soemanegara, Marketing Communication: Taktik \& Strategi (Jakarta: PT. Bhuana Ilmu Populer, 2006), hlm. 63.

Kennedy, J. E., \& Soemanagara, R. D. (2006). Marketing Communication: Taktik \& Strategi. Jakarta: PT. Bhuana Ilmu Populer.

Kotler, P., \& Keller, K. L. (2008). Manajemen Pemasaran. Jakarta: Erlangga.

Kotler dan Keller (2009). Manajemen Pemasaran. Jilid 1. Edisi ke 13.(Jakarta: Erlangga.

Lexy J. Moleong, (2011). Metodologi Penelitian Kualitatif, (Bandung : PT Remaja Rosdakarya.

Muh Tahir, (2011). Pengantar Metodologi Penelitian Pendidikan, (Makassar: Universitas Muhammadiyah Makassar.

Maman, C. (2005). Strategi "Public Relations" dalam Promosi Pariwisata: Studi Kasus dengan Pendekatan "Marketing Public Relations" di Provinsi Banten.

Moleong, M. L. (2011). Metodologi Penelitian Kualitatif. Bandung: PT. Remaja Rosdakarya.

Muhammad, A. (2011). Dalam Komunikasi Organisasi. Jakarta: PT. Bumi Aksara.

Mulyana, D. (2002). Ilmu Komunikasi Suatu Pengantar. Bandung: PT. Remaja Rosdakarya.

Nazi, M. (2005). Metodologi Penelitian. Bogor: Ghalia Indonesia.

Onong Uchjana, (2003). Humas Relation dan Public Relations dalam Manajemen, Bandung: Mandar.

Riswandi. (2010). Ilmu Komunikasi. Yogyakarta: Graha Ilmu.

Rosady Ruslan, (2004). Etika Kehumasaan dan Aplikasinya, Jakarta: PT. Raja Grafindo Persada, Cetakan Ke Tiga.

S., P. N. (1990). Dalam Ilmu Pariwisata Sebuah Pengantar Perdana. Jakarta: PT. Pradnya Paramita.

Tahir, M. (2011). Pengantar Metodologi Penelitian Pendidikan. Makassar: Universitas Muhammadiyah Makassar.

Thomas L. Harris, The Marketer's Guide To Public Relations,(New York: John Wiley\&Sons, Inc., 1993), Hlm. 13.

Uchjana, O. (2003). Human Relation dan Public Relations dalam Manajemen. Bandung: Mandar. 